\title{
DEVELOPING IMMUNOTHERAPIES FOR CHILDHOOD CANCER
}

Anna Capsomidis ${ }^{1}$, John Anderson ${ }^{1}$

${ }^{1}$ Cancer Section, UCL Institute of Child Heath, London, UK

Correspondence: John Anderson, UCL Institute of Child Health, 30 Guilford Street, London, WC1N 1EH. Phone; 00442079052265, Fax; 0207-905-2133, E-mail; j.anderson@ucl.ac.uk

Keywords: Paediatric cancer, tumour antigen, immunotherapy, adoptive T-cell therapy, antibody therapy.

Word count: 816

Number of tables: 2

Number of figures: 1 


\section{INTRODUCTION}

The development of immune-based treatment (immunotherapy) for childhood cancer is a rapidly advancing field with impressive results already achieved in children with leukaemia. ${ }^{12}$ For cancers resistant to conventional treatments, harnessing the power and specificity of the immune system to fight cancer is an attractive alternative approach. The immune system is essential for controlling cancer progression by continual surveillance and elimination of transformed cells. This protective process is hindered by the ability of cancer cells to develop mechanisms enabling them to 'hide' from immune destruction (including down-regulation of tumour-associated antigens and major histocompatibility complex $(\mathrm{MHC})$ class $\mathrm{I}$, and the creation of an immunosuppressive tumour microenvironment). The aims of cancer immunotherapy are to enhance existing anti-tumour immune responses (active immunotherapy), including cancer vaccines and immune check-point inhibitors, or to enable the immune system to specifically recognise and kill cancer cells (passive immunotherapy) (Table 1).

\begin{tabular}{|cc|}
\hline Passive immunotherapy & Active immunotherapy \\
\hline Monoclonal antibodies & Cancer vaccines \\
\hline Bispecific antibodies & Immune check-point inhibitors \\
\hline CAR T-cells \\
\hline TCR-redirected T-cells \\
\hline Tumour infiltrating lymphocytes \\
\hline Viral reactive T-cells \\
\hline Donor lymphocytes \\
\hline
\end{tabular}

Table 1. Classification of immune-based therapies for childhood cancer. Abbreviations: CAR; chimeric antigen receptor, TCR; T-cell receptor. 
The identification of targetable tumour antigens is fundamental to the development of successful 'passive' immunotherapies. Ideally targets should be highly expressed on cancer cells with little or no expression on normal tissue in order to avoid the potential for 'on-target, off-tumour' toxicities. B-lymphocyte antigen CD19 and disialoganglioside GD2 have been selected as suitable antigens for paediatric leukaemia and neuroblastoma immunotherapy clinical trials, respectively. ${ }^{1} 3$ However, neither of these targets are 100\% perfect as CD19-directed therapy causes depletion of healthy B-cells, and GD2 is expressed at low level on normal peripheral nerves.

This article gives a brief overview of the main types of immunotherapy currently under development (Table 2), and addresses some of the main caveats surrounding translation to clinical practice. 


\begin{tabular}{|c|c|c|c|}
\hline Immunotherapy & Description & Advantages & Limitations \\
\hline $\begin{array}{c}\text { Monoclonal } \\
\text { antibodies (MAb) }\end{array}$ & $\begin{array}{c}\text { Bind tumour antigen and augment } \\
\text { antibody-dependent cell-mediated } \\
\text { cytotoxicity (ADCC) e.g. anti-GD2 } \\
\left(\text { Ch14.18) }{ }^{3} \text { and anti-CD20 }\right. \\
(\text { rituximab })^{4} \text {. MAb can also be linked } \\
\text { to chemotherapeutics or } \\
\text { radionuclides. }\end{array}$ & $\begin{array}{l}\text { 'Off the shelf' product } \\
\text { Efficacious in Phase III } \\
\text { clinical trials }\end{array}$ & $\begin{array}{l}\text { Short half-life, requires repeated } \\
\text { administration } \\
\text { 'On target, off tumour' side effects } \\
\text { Anaphylactoid reactions }\end{array}$ \\
\hline Bispecific antibodies & $\begin{array}{l}\text { Simultaneously bind tumour antigen } \\
\text { and T-cell e.g. blinatumomab5 binds } \\
\text { CD19 and CD3 }\end{array}$ & 'Off the shelf' product & $\begin{array}{l}\text { Short half-life, requires repeated } \\
\text { administration } \\
\text { Cytokine release syndrome } \\
\text { Potential for 'antigen escape' }\end{array}$ \\
\hline Checkpoint inhibitors & $\begin{array}{l}\text { e.g. anti-PD-1 or anti-CTLA-4 } \\
\text { (Ipilimumab) antibodies block } \\
\text { inhibitory immune signals }\end{array}$ & 'Off the shelf' product & $\begin{array}{c}\text { Short half-life, requires repeated } \\
\text { administration } \\
\text { Cytokine release syndrome }\end{array}$ \\
\hline Tumour vaccines & $\begin{array}{l}\text { Most commonly Ex vivo production of } \\
\text { autologous tumour antigen pulsed } \\
\text { dendritic cells for injection }\end{array}$ & $\begin{array}{c}\text { Generation of } \\
\text { immunological memory }\end{array}$ & $\begin{array}{c}\text { Patient specific therefore expensive to } \\
\text { produce and requires gene therapy } \\
\text { laboratory }\end{array}$ \\
\hline $\begin{array}{l}\text { Tumour infiltrating } \\
\text { lymphocytes (TILs) }\end{array}$ & $\begin{array}{c}\text { T-cells are extracted from the tumour } \\
\text { itself and cultured ex vivo to large } \\
\text { numbers for infusion }\end{array}$ & $\begin{array}{c}\text { Tumour-specific } \\
\text { Immunological memory }\end{array}$ & $\begin{array}{l}\text { Patient specific } \\
\text { Not reliably produced from all tumour } \\
\text { samples } \\
\text { Limited study in paediatric patients }\end{array}$ \\
\hline Viral reactive T-cells & $\begin{array}{l}\text { T-cells stimulated with viral antigen } \\
\text { expressing antigen presenting cells }\end{array}$ & Immunological memory & $\begin{array}{c}\text { Patient specific } \\
\text { Small number of cells for infusion }\end{array}$ \\
\hline $\begin{array}{l}\text { TCR re-directed T } \\
\text { cells }\end{array}$ & $\begin{array}{c}\text { Autologous T-cells are genetically } \\
\text { modified with tumour antigen specific } \\
\text { T-cell receptors }\end{array}$ & $\begin{array}{c}\text { Immunological memory } \\
\text { Directly target tumour } \\
\text { antigen } \\
\text { Can also target intracellular } \\
\text { antigens }\end{array}$ & $\begin{array}{c}\text { Patient specific } \\
\text { MHC-restricted } \\
\text { Risk of mis-pairing with endogenous } \\
\text { TCR } \\
\text { Cytokine release syndrome }\end{array}$ \\
\hline $\begin{array}{l}\text { CAR re-directed T } \\
\text { cells }\end{array}$ & $\begin{array}{c}\text { Autologous T-cells are genetically } \\
\text { modified with } \\
\text { Chimeric antigen receptors }\end{array}$ & $\begin{array}{l}\text { Immunological memory } \\
\text { Can include 'safety switch' } \\
\text { MHC-unrestricted } \\
\text { Can be engineered with } \\
\text { 'costimulatory' domains to } \\
\text { enhance efficacy and } \\
\text { persistence }\end{array}$ & $\begin{array}{c}\text { Patient specific } \\
\text { Can only target known cell surface } \\
\text { antigens } \\
\text { Cytokine release syndrome } \\
\text { 'On-target, Off tumour' side effects } \\
\text { Potential for 'antigen escape' }\end{array}$ \\
\hline
\end{tabular}


Table 2. Overview of cancer immunotherapy approaches.

Abbreviations: ALL; Acute Lymphoblastic Leukaemia, CNS; central nervous system, EBV; Epstein-Barr virus, CAR; chimeric antigen receptor, TCR; T-cell receptor, MHC; Major histocompatibility complex.

\section{WHAT TYPES OF CANCER IMMUNOTHERAPY ARE BEING DEVELOPED?}

\section{Monoclonal antibodies}

Over the last two decades, the development of monoclonal antibodies to treat cancer has yielded some of the greatest successes. Monoclonal antibodies directly targeting tumour antigens have now been incorporated into many standard paediatric treatment protocols ${ }^{3}$. Bispecific antibodies and bispecific T-cell engagers (BiTE®) bind two targets and can therefore simultaneously bind a tumour antigen and cytotoxic T-cell. ${ }^{5}$

Antibodies have also been engineered to block immune check-points. PD-1 and CTLA-4 are examples of inhibitory co-receptors that provide an immunological break' to uncontrolled T-cell activation. Monoclonal antibodies that target these checkpoints can augment existing inhibited immune responses to cancer. PD-1 blockade has shown great promise in clinical trials for metastatic melanoma ${ }^{6}$ and other adult cancers, and its efficacy is now being tested in paediatric malignancies.

\section{Adoptive cell therapy}

Adoptive cell therapy (ACT) is an example of 'personalised medicine' where autologous tumour specific T-cells are manufactured in the laboratory before reinfusion back into the patient. Approaches in children include the culturing and genetic modification of T-cells to promote activation, proliferation and tumour specificity (Figure 1).

Tumour specificity of T-cells from peripheral blood can be achieved by genetic modification with antigen-specific T-cell receptors (TCRs) or chimeric antigen 
receptors (CARs). CARs combine an extracellular antibody-derived antigen-binding domain with an intracellular T-cell activation domain (Figure 1). CARs have the additional advantage of being unrestricted by MHC, unlike TCRs.

Clinical trials using CD19-directed CAR T-cells for children with refractory leukaemia have achieved greater than $70 \%$ remission rates. ${ }^{1}$ A research priority is now to translate expertise to solid tumours and a key challenge will be engineering CAR Tcells that effectively traffic to tumour sites, and form immunological memory.

Naturally occurring tumour-reactive T-cells can also be derived and propagated from tumour tissue itself under special culture conditions (known as tumour infiltrating lymphocytes, TILs), although there has been little clinical experience to date for childhood solid tumours.

\section{Cancer vaccines}

An example of active immunotherapy is through vaccination, however clinical trials aimed at inducing anti-tumour immune responses have so far been disappointingly ineffective in children with cancer.

\section{TRANSLATING IMMUNOTHERAPY INTO CLINICAL PRACTICE}

The development of novel immunotherapies must include rigorous pre-clinical testing to fully assess any potential harm to patients. Toxicities can be divided into two groups; those related to autoimmunity ('on-target, off tumour effects') and those relating to an increase in circulating cytokines (e.g. leading to cytokine-release syndrome). ${ }^{7}$ Learning how to recognise and manage these toxicities will be key following translation to large-scale clinical trials.

The manufacture of a personalised immunotherapeutic is a highly complex and labour-intensive process that is currently restricted to just a few centres in the UK. Hence, currently treatment is limited to a small number of patients within a clinical trial setting. CD19 CAR T-cells however are now being commercialised for much wider application and one exciting development is 'off the shelf' rather than 'patient- 
specific' therapies achievable through "genome editing" in which third party donor cells can be silenced for immune attack through deletion of genes such as MHC.

\section{CONCLUSION}

There has been a paradigm shift in adult oncology through the developments of cancer immunotherapy. For paediatrics, a major rate-limiting step has been the identification of optimal targetable tumour antigens. Combinational therapies with standard treatments or other immune-based treatments to overcome the immunoinhbitory microenvironment is a current research priority.

Competing Interests: No potential conflicts of interests declared

Funding: $A C$ is a Clinical Research Training Fellow supported by the Wellcome Trust, Great Ormond Street Hospital Children's Charity and Great Ormond Street Hospital Biomedical Research Centre. JA is funded by the Great Ormond Street Charity leadership award and Great Ormond Street Hospital NIHR Biomedical Research Centre.

Contributorship: AC drafted the manuscript. JF provided critical review of the draft. Both authors approved the final version.

\section{REFERENCES}

1. Maude SL, Frey N, Shaw PA, et al. Chimeric antigen receptor T cells for sustained remissions in leukemia. The New England journal of medicine 2014;371(16):1507-17.

2. Mackall CL, Merchant MS, Fry TJ. Immune-based therapies for childhood cancer. Nature reviews Clinical oncology 2014;11(12):693-703.

3. Yu AL, Gilman AL, Ozkaynak MF, et al. Anti-GD2 antibody with GM-CSF, interleukin-2, and isotretinoin for neuroblastoma. The New England journal of medicine 2010;363(14):1324-34.

4. Samochatova EV, Maschan AA, Shelikhova LN, et al. Therapy of advanced-stage mature B-cell lymphoma and leukemia in children and adolescents with 
rituximab and reduced intensity induction chemotherapy (B-NHL 2004M protocol): the results of a multicenter study. Journal of pediatric hematology/oncology 2014;36(5):395-401.

5. Schlegel P, Lang P, Zugmaier G, et al. Pediatric posttransplant relapsed/refractory B-precursor acute lymphoblastic leukemia shows durable remission by therapy with the T-cell engaging bispecific antibody blinatumomab. Haematologica 2014;99(7):1212-9.

6. Metcalfe W, Anderson J, Trinh VA, et al. Anti-programmed cell death-1 (PD-1) monoclonal antibodies in treating advanced melanoma. Discovery medicine 2015;19(106):393-401.

7. Lee DW, Gardner R, Porter DL, et al. Current concepts in the diagnosis and management of cytokine release syndrome. Blood 2014;124(2):188-95.

\section{FIGURE LEGENDS}

Figure 1 - Production of autologous chimeric antigen receptor (CAR) engineered Tcells for patient infusion. 